\title{
Effects of an adenoviral vector containing a suicide gene fusion on growth characteristics of breast cancer cells
}

\author{
HENG KONG ${ }^{1,2}$, CHUNLI LIU $^{3}$, TING ZHU $^{4}$, ZONGHAI HUANG $^{5}$, LIUCHENG YANG $^{5}$ and QIANG LI ${ }^{5}$ \\ ${ }^{1}$ Department of Breast and Thyroid Surgery, Shenzhen Sixth People's Hospital, Shenzhen, Guangdong 518052, P.R. China; \\ ${ }^{2}$ Cancer Center, Georgia Regents University, Augusta, Georgia 30912, USA; \\ Departments of ${ }^{3}$ Special Care Center and ${ }^{4}$ Ultrasound, Shenzhen Sixth People's Hospital, Shenzhen, Guangdong 518052; \\ ${ }^{5}$ Department of General Surgery, Zhujiang Hospital, Southern Medical University, Guangzhou, Guangdong 510282, P.R. China
}

Received December 27, 2013; Accepted July 22, 2014

DOI: $10.3892 / \mathrm{mmr} .2014 .2631$

\begin{abstract}
The herpes simplex virus thymidine kinase/ganciclovir (HSV-TK/GCV) and the cytosine deaminase/5-fluorocytosine (CD/5-FC) systems have been widely applied in suicide gene therapy for cancer. Although suicide gene therapy has been successfully used in vitro and in vivo studies, the number of studies on the effects of recombinant adenoviruses (Ads) containing suicide genes on target cancer cells is limited. The aim of this study was to examine whether recombinant Ads containing the $C D / T K$ fusion gene affect cell proliferation of breast cancer cells in vitro. In the present study, we explored the use of a recombinant adenoviral vector to deliver the $C D / T K$ fusion gene to the breast cancer cell line MCF-7. We found that the recombinant adenoviral vector efficiently infected MCF-7 cells. Western blot analysis revealed that $\mathrm{CD}$ and $\mathrm{TK}$ proteins are expressed in the infected cells. The infected breast cancer cells did not show any significant changes in morphology, ultrastructure, cell growth, and cell-cycle distribution compared to the uninfected cells. This study revealed that the Ad-vascular endothelial growth factor promoter (VEGFp)-CD/TK vector is non-toxic to MCF-7 cells at the appropriate titer. Our results indicate that it is feasible to use a recombinant adenoviral vector containing the $C D / T K$ fusion gene in suicide gene therapy to target breast cancer cells.
\end{abstract}

\section{Introduction}

The cytosine deaminase/5-fluorocytosine (CD/5-FC) and the thymidine kinase/ganciclovir (TK/GCV) are the most

Correspondence to: Dr Heng Kong, Department of Breast and Thyroid Surgery, Shenzhen Sixth People's Hospital, 89 Taoyuan Road, Shenzhen, Guangdong 518052, P.R. China

E-mail: generaldoc@126.com

Key words: adenovirus vector, cancer gene therapy, breast cancer, green fluorescent protein common suicide gene therapy systems $(1,2)$. Several studies have adopted strategies making use of the CD/5-FC and the herpes simplex virus thymidine kinase/ganciclovir (HSV-TK/GCV) systems, which are more effective when combined as compared to their use alone (3-5). However, relatively few reports exist on the effect of the vector combining the two systems on cancer cells. Therefore, we initiated experiments to assess the effect of a recombinant adenovirus (Ad) containing the $C D / T K$ fusion gene on MCF-7 cells, in order to contribute to the development of new strategies for the improvement of the clinical application of current double suicide gene therapy protocols.

Recombinant adenoviral (Ad) vectors have been widely used as a gene delivery vehicle, since they can efficiently transfer genes into a wide spectrum of cell types at a high efficiency in vitro and in vivo (6-8). One of the major goals of cancer gene therapy is to increase selective death of cancer cells. To achieve this, a number of methods have been adopted, based on either cell type-specific receptors allowing targeted gene delivery, or tissue-specific promoters allowing heterologous gene expression in specific organs (9-11); these methods have in general proven satisfactory in vitro. Based on the overexpression of the vascular endothelial growth factor (VEGF) in breast cancer cells and the absence of its expression in healthy breast tissues $(12,13)$, a recombinant Ad carrying the $V E G F$ gene promoter and the $C D / T K$ fusion gene, named Ad-VEGFp-CD/TK, was previously constructed by our group (14). This vector is expected to allow specific expression of the fusion suicide gene $(C D / T K)$ via the $V E G F$ promoter.

In the present study, we investigated whether the suicide gene fusion $C D / T K$ driven by the $V E G F$ promoter can achieve high-efficiency gene transfer and high-level expression of the CD and TK proteins in MCF-7 breast cancer cells. Moreover, we studied the effects of the recombinant Ad containing the $C D / T K$ gene fusion on the morphology and growth characteristics of breast cancer cells. We investigated the feasibility of the approach using the $V E G F$-driven $C D$ and $T K$ genes to target breast cancer cells in vitro. Since $V E G F$ is overexpressed in numerous solid tumors, this approach may improve selectivity towards cancer cells and may be applicable on a wide range of tumors. 


\section{Materials and methods}

Cell culture. The human embryonic kidney epithelial 293 (HEK-293) and the breast cancer MCF-7 cell lines were obtained from the American Type Culture Collection (Manassas, VA, USA). As previously described (14), MCF-7 cells and HEK-293 cells were cultured in Dulbecco's modified Eagle's medium (DMEM; Invitrogen Life Technologies, Carlsbad, CA, USA) containing $10 \%$ fetal bovine serum (Invitrogen Life Technologies) in an incubator at $5 \% \mathrm{CO}_{2}$, at $37^{\circ} \mathrm{C}$. When the cells had reached $90 \%$ confluence, they were digested into single cell suspensions using trypsin (Amresco, Solon, OH, USA). Cells were harvested and subcultured. Subsequently, cells in logarithmic growth phase were selected for investigation.

Recombinant adenoviral vector. The recombinant $\mathrm{Ad}$ carrying the $V E G F$ gene promoter and the $C D / T K$ fusion gene, named Ad-VEGFp-CD/TK, was previously constructed and preserved by our group (14). The vector also contains the green fluorescence protein reporter gene $(G F P)$, which was used as a marker for the delivery of target genes into MCF-7 cells. The vector was repeatedly transfected into HEK-293 cells to allow amplification. Next, the Ads were purified by caesium chloride gradient ultracentrifugation at $32,000 \mathrm{xg}$, at $15^{\circ} \mathrm{C}$, for $1 \mathrm{~h}$. Subsequently, the adenoviral titers were determined with the endpoint dilution assay and the plaque forming units (pfu) were assessed with a plaque assay, as described in $(14,15)$, respectively. The titer of Ad-VEGFp-CD/TK was $2.2 \times 10^{11} \mathrm{pfu} / \mathrm{ml}$.

Adenoviral infection. Four million MCF-7 cells were inoculated in each well of 6-well plates. Cultures were maintained for $12 \mathrm{~h}$, and cells were then infected with Ad-VEGFp-CD/TK at multiplicities of infection (MOI) of 20,40,60, 80, 100 and $200 \mathrm{pfu} / \mathrm{cell}$, for $24 \mathrm{~h}$. The number of GFP-positive cells was counted under an inverted fluorescence microscope (Leica, Mannheim, Germany).

Microscopy and cellular morphology. The experimental group was infected for $24 \mathrm{~h}$ with the adenoviral vector at MOI 100. The control group was cultured in DMEM for $24 \mathrm{~h}$. One day later, the cells in the two groups entered the logarithmic growth phase. The morphological changes of MCF-7 cells were examined under a phase contrast light microscope (Leica, Mannheim, Germany).

Transmission electron microscopy (TEM). MCF-7 cells were incubated overnight in a $75-\mathrm{ml}$ cell culture bottle. Then, the experimental group was incubated with the adenoviral vector Ad-VEGFp-CD/TK for $72 \mathrm{~h}$ at $37^{\circ} \mathrm{C}$ with $5 \% \mathrm{CO}_{2}$. The control group was cultured in DMEM for $72 \mathrm{~h}$. The cultured cells were harvested using trypsin and centrifuged for $10 \mathrm{~min}$ at $2,000 \mathrm{xg}$ at room temperature. The pellets were next fixed overnight in $3 \%(\mathrm{v} / \mathrm{v})$ glutaraldeyde at $4^{\circ} \mathrm{C}$. The specimens were washed in phosphate-buffered saline (PBS) and post-fixed in $1 \%$ osmium tetraoxide for $20 \mathrm{~min}$. Then, the specimens were dehydrated in a graded series of acetone dilutions. The area of interest in the resin block containing the embedded cells was selected using toluidine blue staining (Polysciences, Warrington, PA,
USA), and later examined under a light microscope. Ultrathin sections of the selected area were performed using a Leica EM UC7 ultramicrotome (Leica). The stained samples were then observed using TEM (Philips, Eindhoven, The Netherlands). The nucleus-to-cytoplasm ratio was evaluated using the ratio of the volume size of the cell nucleus to the volume size of the cell cytoplasm.

Western blot analysis. MCF-7 cells were inoculated on 90-mm dishes and transduced with recombinant Ads for $24 \mathrm{~h}$ using the protocol of adenovirus vector infection. Cells were then lysed using lysis buffer $(50 \mathrm{mM}$ Tris/pH 8.0, $150 \mathrm{mM} \mathrm{NaCl}, 1 \%(\mathrm{w} / \mathrm{v})$ Triton-X-100, 0.1\% (w/v) SDS, $1 \%$ (w/v) sodium deoxycholate) and proteins were extracted from the MCF-7 cell lysate by centrifugation (Sigma, Deisenhofen, Germany) at $14,000 \mathrm{x} \mathrm{g}$ for $10 \mathrm{~min}$. The extracted proteins were subjected to sodium dodecyl sulfate-polyacrylamide gel electrophoresis, then transferred onto a polyvinylidene fluoride membrane. Subsequently, the membrane was incubated with $30 \mathrm{~g} / \mathrm{l}$ non-fat milk, and next, with sheep anti-CD (Biogenesis, Poole, UK) or goat anti-TK (Santa Cruz Biotechnology, Inc., Santa Cruz, CA, USA) antibodies overnight at $4^{\circ} \mathrm{C}$. After a wash in Tris-buffered saline with Tween-20 (TBST), horseradish peroxidase-labeled rabbit anti-sheep or anti-goat IgG was added as the secondary antibody (Santa Cruz Biotechnology, Inc.), and incubated at room temperature for $1 \mathrm{~h}$. The membrane was washed with TBST, and incubated with an enhanced chemiluminescence substrate (ECL; Merck KGaA, Darmstadt, Germany) for $1 \mathrm{~min}$. Finally, the membrane was developed on an X-ray film (Fujifilm, Tokyo, Japan).

Cell growth curve. Transfected MCF-7 cells were inoculated on 24-pore plates at a density of $1 \times 10^{4} /$ pore. The control group was untransfected MCF-7 cells. Three parallel pores were assayed for each group. MCF-7 cells were observed and counted each day for 7 consecutive days in order to establish the growth curve.

Flow cytometry (FCM) analysis. FCM analysis was used to assess the distribution of MCF-7 cells at the different cell cycle stages, as in (16). Briefly, 5x10 ${ }^{5}$ MCF-7 cells at the logarithmic growth phase were inoculated in a $50-\mathrm{ml}$ cell culture bottle. The experimental group was cultured with the adenoviral vector (Ad-VEGFp-CD/TK) for $72 \mathrm{~h}$ at $37^{\circ} \mathrm{C}$ with $5 \% \mathrm{CO}_{2}$. The control group was cultured in DMEM for $72 \mathrm{~h}$. The cultured cells were harvested using trypsin and washed in PBS. The pelleted cells were later fixed in cold absolute ethanol (final concentration, $70 \%$ ) overnight at $4{ }^{\circ} \mathrm{C}$. The cell suspension was rewashed using PBS and centrifuged at 1,000 $\mathrm{x}$ g for $10 \mathrm{~min}$. After the ethanol was discarded, $200 \mu \mathrm{l}$ of RNase $(1 \mathrm{mg} / \mathrm{ml}$; Sigma, St. Louis, MO, USA) were added to the pellet, which was gently mixed. The samples were kept at $37^{\circ} \mathrm{C}$ for $60 \mathrm{~min}$. Subsequently, $800 \mu \mathrm{l}$ of propidium iodide $(0.5 \mathrm{mg} / \mathrm{ml}$; Sigma) were added to $400 \mu \mathrm{l}$ of each cell suspension, and were left to incubate for $30 \mathrm{~min}$ at $4^{\circ} \mathrm{C}$. FCM was then performed on a FACSCaliber cytometer (Becton Dickinson, San Jose, CA, USA). The ModFit LT software (Verity, Topsham, ME, USA) was used for data quantification.

Statistical analysis. The experimental data were processed with the SPSS 13.0 software (SPSS, Inc., Chicago, IL, USA). Data were expressed as mean \pm standard error of the mean (SEM). 


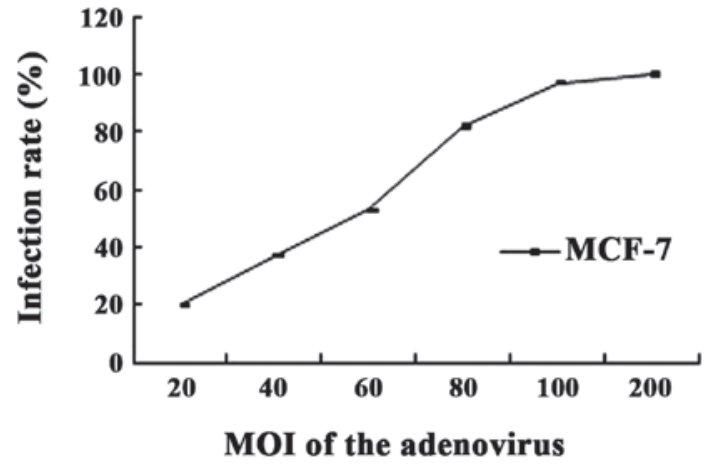

Figure 1. Percentage of infected cells based on multiplicities of infection (MOI).
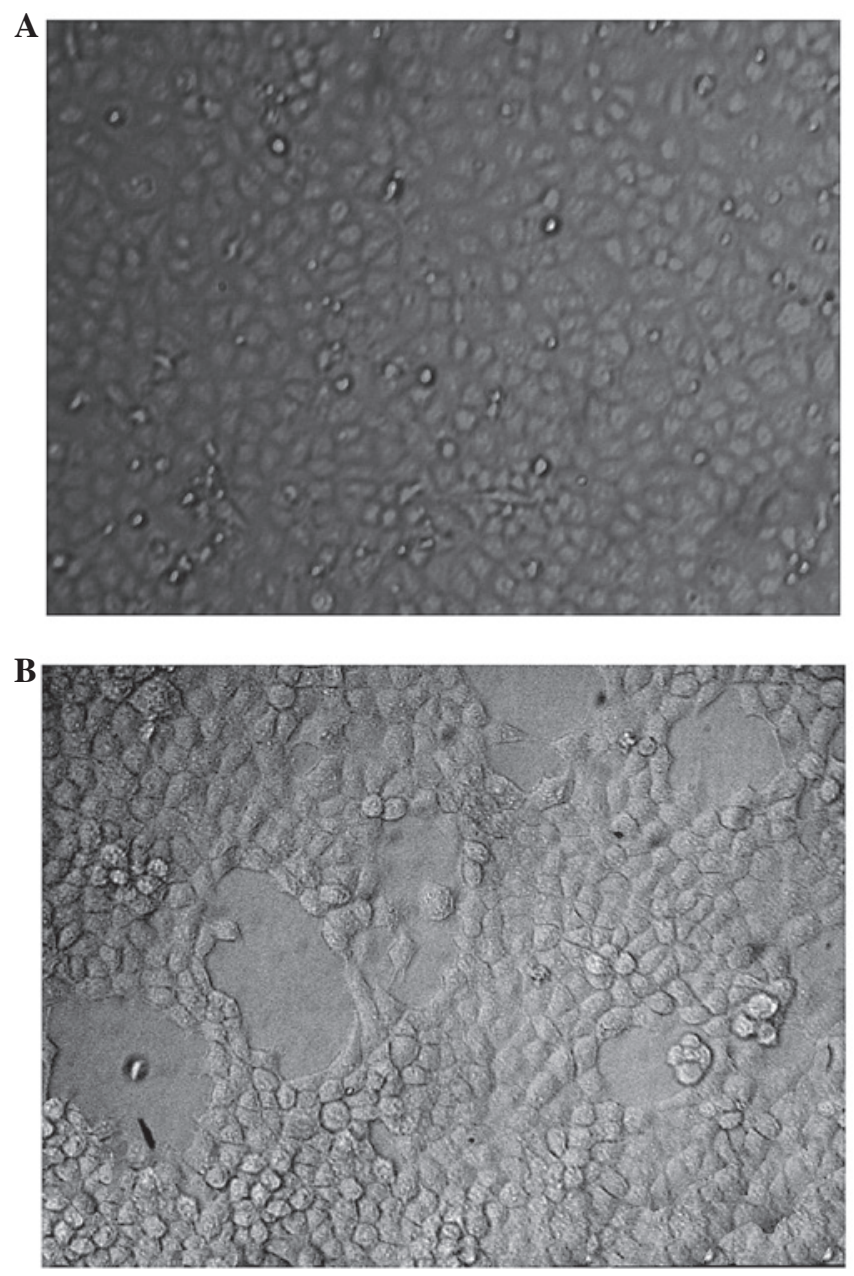

Figure 2. Morphology of MCF-7 cells prior to and following infection with the adenovirus, as observed under a phase contrast microscope (magnification, $\mathrm{x} 200$ ). (A) Non-transfected cells and (B) experimental group of cells transfected with the adenoviral vector for $24 \mathrm{~h}$.

An independent samples t-test was used to compare the means between two groups. $\mathrm{P}<0.05$ was considered to indicate statistically significant differences.

\section{Results}

Effective infection of the adenoviral vector in $M C F-7$ cells. We estimated the transduction efficiencies of the adenoviral-medi-
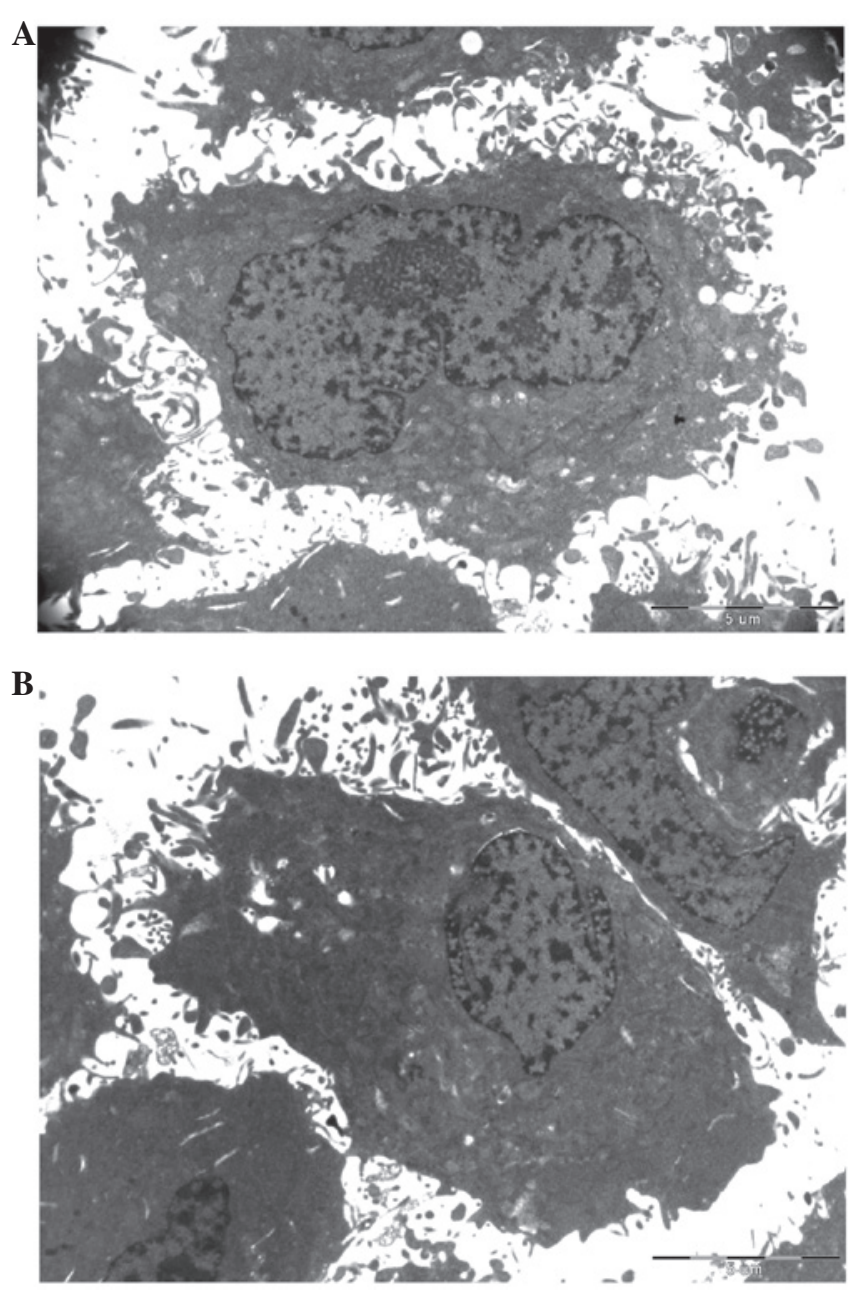

Figure 3. Ultrastructural features of MCF-7 cells prior to and following infection with the adenovirus, as observed under an electron microscope (magnification, x8,000). (A) Control group, untransfected cells and (B) experimental group, cells transfected with the adenovirus for $72 \mathrm{~h}$.

ated gene transfer in human breast cancer cells infected at different MOI of the Ad vector. As the MOI increased, the percentage of infected cells also increased (Fig. 1). At MOI of 100 and 200 pfu/cell, >95\% of MCF-7 cells were GFP-positive, without any obvious toxicity effects observed. Therefore, we concluded that the adenoviral vector efficiently infects the human breast cancer cells in vitro.

Effect of infection on cell morphology. MCF-7 cells were treated with the adenoviral vector at MOI 100 for $24 \mathrm{~h}$. The infection toxicity was then evaluated by observations of the cell morphology (Fig. 2). No change in cellular morphology was observed after the 24-h treatment of the cells with the adenoviral vector (Fig. 2B). The adherent cells typically show a polygonal, spreading shape, with a large nucleus. However, we found that cell densities in the experimental group (transfected cells) were reduced compared to the control group. We explored whether cell density may be associated with the cell proliferation rate by cell growth and cell cycle analyses described below.

Ultrastructure of MCF-7 cells. As revealed by TEM, the ultrastructure of the transfected MCF-7 cells (Fig. 3B, 


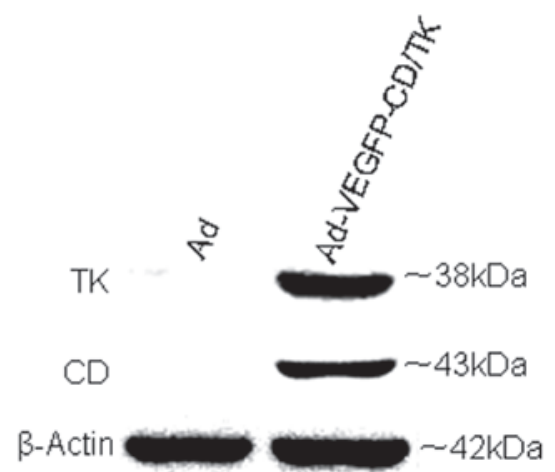

Figure 4. Western blot analysis shows that cytosine deaminase (CD) and thymidine kinase (TK) are expressed in protein extracts prepared from MCF-7 cell lysates of infected MCF-7 cells, but not of control cells.

experimental group) was similar to that of the non-transfected MCF-7 cells (Fig. 3A, control group). The centrally placed nucleus commonly contained one or two prominent nucleoli. The nucleus-to-cytoplasm ratio was 1:1.

Expression of $C D$ and TK proteins. The expression of the $\mathrm{CD}$ and TK proteins was analyzed by western blot analysis. The results showed that the CD and TK proteins are not expressed in the control group, while they were strongly expressed in the experimental group (Fig. 4).

Cell growth curve of MCF-7 cells. MCF-7 cells were observed under a light microscope following an additional 72-h incubation with the adenoviral vector. The morphology of MCF-7 cells of the experimental group was similar to that of the control group. The growth of cells became relatively slow at one to two days after infection, while growth rates increased after two days. An increasing number of cells became cell growth arrested and eventually senescent from the fifth day onwards. Cell proliferation of the experimental group was reduced compared to the control group (Fig. 5). The data from cell growth experiments were statistically analyzed using an independent samples t-test. There was no significant difference in cell proliferation between the two groups $(\mathrm{P}>0.056)$. This result showed that the adenoviral vector has no obvious effect on MCF-7 cell growth (Table I and Fig. 5).

Cell cycle analysis using FCM. The proportion of cells at the different phases of the cell cycle is shown in Table II. The data from the experimental and the control group were statistically analyzed by an independent samples t-test, which revealed no significant differences $(\mathrm{P}>0.085)$ in the number of cells at the same phase of the cell cycle between the two groups (Table II). In addition, FCM analysis revealed that the adenoviral vector has no obvious effect on the cell cycle distribution of MCF-7 cells (Fig. 6).

\section{Discussion}

Adenoviral vectors are popular gene delivery vectors in clinical trials for gene therapy (17-19). There are several advantages of using adenoviral vectors: first, the efficiency

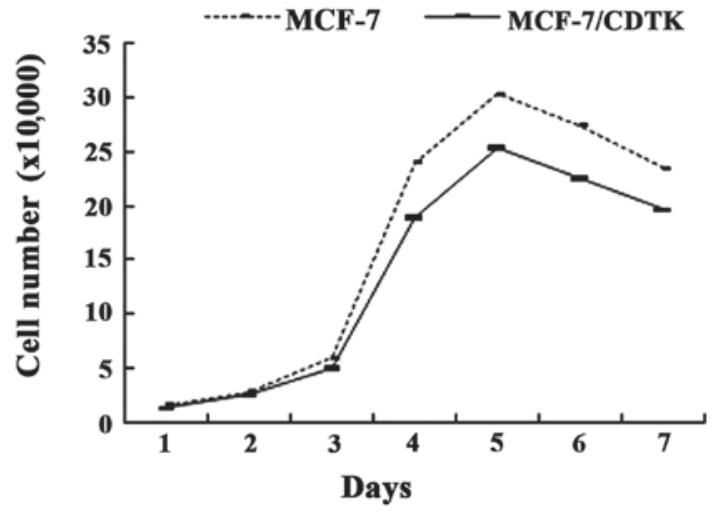

Figure 5. Growth curves of MCF-7 cells and of MCF-7 cells transfected with the adenoviral vector (MCF-7/CDTK).
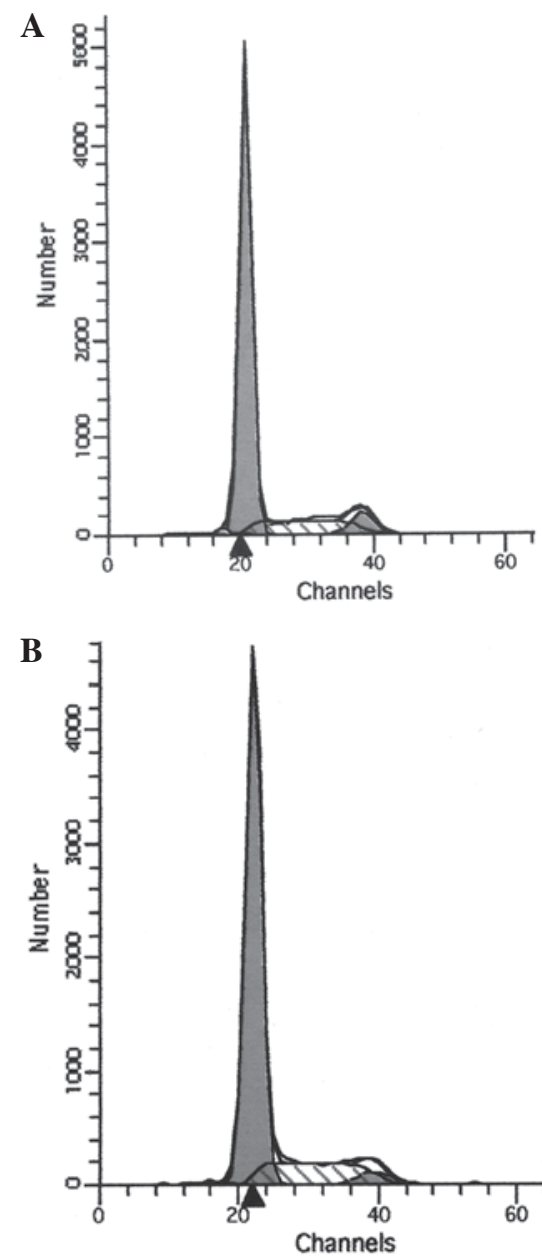

Figure 6. Changes in the cell cycle of (A) untransfected and (B) transfected MCF-7 cells, as examined by flow cytometry.

of transduction is high, as is the level of gene expression $(20,21)$. In this study, we used an adenoviral vector containing the GFP reporter gene, which is a commonly used reporter allowing to unequivocally assess whether a gene is expressed. GFP expression was evaluated by fluorescence microscopy, which allowed to assess the efficiency of transduction. This experiment demonstrated that $>95 \%$ of the cells were GFP-positive at a MOI of 100 and $200 \mathrm{pfu} / \mathrm{cell}$. The recombinant adenoviral vector showed no 
Table I. Number of MCF-7 cells at different days of infection (mean x10 $\pm \mathrm{SD}, \mathrm{n}=3$ ).

\begin{tabular}{lccccccc}
\hline & \multicolumn{7}{c}{ Days of infection } \\
\cline { 2 - 7 } Group & 1 & 2 & 3 & 4 & 5 & 6 & 7 \\
\hline MCF-7 & $1.56 \pm 0.14$ & $2.80 \pm 0.26$ & $5.97 \pm 0.58$ & $23.99 \pm 2.92$ & $30.32 \pm 2.95$ & $27.44 \pm 2.58$ & $23.45 \pm 2.09$ \\
MCF-7/CDTK & $1.31 \pm 0.11$ & $2.56 \pm 0.19$ & $5.01 \pm 0.27$ & $18.90 \pm 2.35$ & $25.35 \pm 2.14$ & $22.51 \pm 1.92$ & $19.64 \pm 1.67$ \\
$\mathrm{t}$ & 2.463 & 1.265 & 2.574 & 2.349 & 2.363 & 2.659 & 2.469 \\
$\mathrm{P}$ & 0.069 & 0.274 & 0.062 & 0.079 & 0.077 & 0.056 & 0.069 \\
\hline
\end{tabular}

$\mathrm{SD}$, standard deviation; MCF-7/CDTK, MCF-7 cells infected with the adenoviral vector; $\mathrm{t}$, a parameter based on an analysis of $\mathrm{t}-\mathrm{test}$; P>0.05, between the MCF-7/CDTK group and the MCF-7 group.

Table II. Cell cycle changes in MCF-7 cells following infection with the adenoviral vector (mean $\%$ of cells $\pm \mathrm{SD}, \mathrm{n}=3$ ).

\begin{tabular}{lccc}
\hline Group & $\mathrm{G}_{0}-\mathrm{G}_{1}$ & $\mathrm{G}_{2}-\mathrm{M}$ & $\mathrm{S}$ \\
\hline Control & $77.03 \pm 3.27$ & $7.89 \pm 1.43$ & $15.01 \pm 1.41$ \\
Transfected & $73.55 \pm 7.34$ & $10.77 \pm 1.66$ & $15.46 \pm 1.53$ \\
$\mathrm{t}$ & 0.749 & 2.279 & 0.375 \\
$\mathrm{P}$ & 0.496 & 0.085 & 0.727 \\
\hline
\end{tabular}

$\mathrm{SD}$, standard deviation; control; untransfected cells; t, a parameter based on an analysis of t-test; $\mathrm{P}>0.05$ between the transfected group and the control group.

toxicity to MCF-7 cells at MOI 100 and 200 (Fig. 2B and C). Second, adenoviral vectors can accommodate relatively large segments of DNA (up to $7.5 \mathrm{~kb}$ ), which they can transduce into the target cells. In this study, the $C D / T K$ fusion gene was $2.4 \mathrm{~kb}$. The $\mathrm{CD}$ and TK proteins were successfully expressed in MCF-7 cells infected with the adenoviral vector, as shown by western blot analysis (Fig. 4). A major disadvantage of current adenoviral vectors is their cytotoxicity to target cells. Teramoto et al (22) showed that adenoviral vectors directly alter the cell cycle in the infected airway cells, which may result in slower proliferation: slower proliferation and cell apoptosis were observed in cells infected by vector at a MOI of $10^{4}$. Slower proliferation and cell apoptosis following Ad vector administration may be due to the high adenoviral titer. If we select an appropriate adenoviral titer, cell proliferation may be not affected, as discussed below.

The VEGF protein has been shown to be upregulated in numerous types of cancer $(23,24)$, including human breast cancer cells $(25,26)$. A VEGF promoter-based adenoviral vector strategy has been successfully adopted to introduce a foreign gene into cancer cells $(27,28)$. However, this strategy has not been systematically explored in breast cancer research. Our study will thus provide valuable information on the use of adenoviral vectors for breast cancer therapy. Our previous studies successfully constructed and extensively analyzed the adenoviral vector Ad-VEGFp-CD/TK $(14,29)$. In the present study, we compared the expression levels of $\mathrm{CD}$ and TK protein (using $\beta$-actin as the loading control) between untransfected and transfected MCF-7 cells by western blot analysis. This analysis showed that the expression levels of $\mathrm{CD}$ and $\mathrm{TK}$ in transfected cells are similar to the expression level of $\beta$-actin. Thus, the VEGF promoter activated CD and TK protein expression in MCF-7 cells. We conclude that VEGF promoter-based Ads have good potential to be developed as effective therapeutic agents for cancer.

This study indicated that infection with the Ad-VEGFp-CD/TK vector exerts no prominent effect on cell proliferation in the human breast cancer cell line MCF-7 at a MOI of 100. Therefore, MOI 100 was selected as the working concentration. We found that infected MCF-7 cells have a lower growth rate than the uninfected cells. However, there was no significant difference $(\mathrm{P}>0.05)$ in cell proliferation between these two groups (Table I). The result from cell growth analysis was consistent with that of cell cycle analysis with flow cytometry: no significant difference $(P>0.05)$ was observed between the two groups with regards to the number of cells at the same phase of the cell cycle (Table II). It is thus reasonable to hypothesize that the adenoviral vector does not alter the cell cycle in the infected MCF-7 cells, which results in the unchanged proliferation of these cells. In addition, no significant change in cell morphology or ultrastructure was observed under the light and the transmission electron microscope. These results indicate that the vector Ad-VEGFp-CD/TK is non-toxic to MCF-7 cells. Three additional studies have successfully used this vector (30-32). Therefore, our study provided the missing information needed for further use of the vector in the context of suicide gene therapy for cancer.

In summary, we achieved high-efficiency transduction of MCF-7 cells by a VEGF promoter-based adenoviral vector, and stable expression of the $\mathrm{CD}$ and TK proteins in vitro. There were no significant changes in cell morphology, ultrastructure, proliferation rate and cell-cycle distribution in the infected MCF-7 cells. We conclude that the VEGF promoter-based suicide gene system may be an effective strategy for cancer treatment, and that the Ad-VEGFp-CD/TK vector is non-toxic to MCF-7 cells at the appropriate titer.

\section{Acknowledgements}

This study was supported in part by the Shenzhen Council for Scientific and Technological Innovation grant JCYJ20130402151227177, and the Shenzhen Nanshan District Science and Technology Project grant 2012025. 


\section{References}

1. Finzi L, Kraemer A, Capron C, Noullet S, Goere D, Penna C, Nordlinger B, Legagneux J, Emile JF and Malafosse R: Improved retroviral suicide gene transfer in colon cancer cell lines after cell synchronization with methotrexate. J Exp Clin Cancer Res 30: $92,2011$.

2. Jia W, Mei L, Wang Y, Liu L and Che G: Double suicide genes selectively kill human umbilical vein endothelial cells. Virol J 8: 74, 2011.

3. Liu T, Ye L, He Y, Chen X, Peng J, Zhang X, Yi H, Peng F and Leng A: Combination gene therapy using VEGF-shRNA and fusion suicide gene yCDglyTK inhibits gastric carcinoma growth. Exp Mol Pathol 91: 745-752, 2011.

4. Niu HX, Du T, Xu ZF, Zhang XK and Wang RG: Role of wild type p53 and double suicide genes in interventional therapy of liver cancer in rabbits. Acta Cir Bras 27: 522-528, 2012

5. Lee SW, Lee YL, Lee YJ, Park SY, Kim IS, Choi TH, Ha JH, Ahn BC and Lee J: Enhanced antitumor effects by combination gene therapy using MDR1 gene shRNA and HSV1-tk in a xenograft mouse model. Cancer Lett 291: 83-89, 2010.

6. Kim HA, Nam K, Lee M and Kim SW: Hypoxia/hepatoma dual specific suicide gene expression plasmid delivery using bio-reducible polymer for hepatocellular carcinoma therapy. J Control Release 171: 1-10, 2013.

7. Li S, Tokuyama T, Yamamoto J, Koide M, Yokota N and Namba H: Potent bystander effect in suicide gene therapy using neural stem cells transduced with herpes simplex virus thymidine kinase gene. Oncology 69: 503-508, 2005.

8. Yi BR, Choi KJ, Kim SU and Choi KC: Therapeutic potential of stem cells expressing suicide genes that selectively target human breast cancer cells: Evidence that they exert tumoricidal effects via tumor tropism (Review). Int J Oncol 41: 798-804, 2012.

9. Jiang YX, Lu Y, Liu TJ, Yang J, Chen Y and Fang YW: Using HSV-TK/GCV suicide gene therapy to inhibit lens epithelial cell proliferation for treatment of posterior capsular opacification. Mol Vis 17: 291-299, 2011.

10. Yu BF, Wu J, Zhang Y, Sung HW, Xie J and Li RK: Ultrasound-targeted HSVtk and Timp3 gene delivery for synergistically enhanced antitumor effects in hepatoma. Cancer Gene Ther 20: 290-297, 2013.

11. Kuzmin D, Gogvadze E, Kholodenko R, Grzela DP, Mityaev M, Vinogradova T, Kopantzev E, Malakhova G, Suntsova M, Sokov D, Ivics Z and Buzdin A: Novel strong tissue specific promoter for gene expression in human germ cells. BMC Biotechnol 10: 58, 2010.

12. Foekens JA, Peters HA, Grebenchtchikov N, Look MP, Meijer-van Gelder ME, Geurts-Moespot A, van der Kwast TH, Sweep CG and Klijn JG: High tumor levels of vascular endothelial growth factor predict poor response to systemic therapy in advanced breast cancer. Cancer Res 61: 5407-5414, 2001.

13. Konecny GE, Meng YG, Untch M, Wang HJ, Bauerfeind I, Epstein M, Stieber P, Vernes JM, Gutierrez J, Hong K, Beryt M, Hepp H, Slamon DJ and Pegram MD: Association between HER-2/neu and vascular endothelial growth factor expression predicts clinical outcome in primary breast cancer patients. Clin Cancer Res 10: 1706-1716, 2004.

14. Chen JF, Huang ZH, Huang YY, Song HJ and Che XY: Construction of recombinant adenoviruses encoding TK suicide gene driven by VEGF promoter using efficient AdEasier-1 system. Ai Zheng 23: 1093-1097, 2004 (In Chinese).

15. Rabenau HF, Rapp I, Steinmann J: Can vaccinia virus be replaced by MVA virus for testing virucidal activity of chemical disinfectants? BMC Infect Dis 10: doi: 10.1186/1471-2334-10-185, 2010.

16. Zhao W, Song Y, Xu B and Zhan Q: Overexpression of centrosomal protein Nlp confers breast carcinoma resistance to paclitaxel. Cancer Biol Ther 13: 156-163, 2012.
17. Puntel M, A K M GM, Farrokhi C, et al: Safety profile, efficacy, and biodistribution of a bicistronic high-capacity adenovirus vector encoding a combined immunostimulation and cytotoxic gene therapy as a prelude to a phase I clinical trial for glioblastoma. Toxicol Appl Pharmacol 268: 318-330, 2013.

18. Muhammad AK, Xiong W, Puntel M, Farrokhi C, Kroeger KM, Salem A, Lacayo L, Pechnick RN, Kelson KR, Palmer D, Ng P, Liu C, Lowenstein PR and Castro MG: Safety profile of gutless adenovirus vectors delivered into the normal brain parenchyma: implications for a glioma phase 1 clinical trial. Hum Gene Ther Methods 23: 271-284, 2012.

19. Castro JE, Melo-Cardenas J, Urquiza M, Barajas-Gamboa JS, Pakbaz RS and Kipps TJ: Gene immunotherapy of chronic lymphocytic leukemia: a phase I study of intranodally injected adenovirus expressing a chimeric CD154 molecule. Cancer Res 72: 2937-2948, 2012.

20. Reetz J, Genz B, Meier C, Kowtharapu BS, Timm F, Vollmar B, Herchenröder O, Abshagen K and Pützer BM: Development of adenoviral delivery systems to target hepatic stellate cells in vivo. PLoS One 8: e67091, 2013.

21. Zhang H, Sui A, Wang Z, Liu S and Yao R: Adenovirus-mediated TRAIL expression and downregulation of Bcl-2 expression suppresses non-small cell lung cancer growth in vitro and in vivo. Int J Mol Med 30: 358-364, 2012.

22. Teramoto S, Johnson LG, Huang W, Leigh MW and Boucher RC: Effect of adenoviral vector infection on cell proliferation in cultured primary human airway epithelial cells. Hum Gene Ther 6: 1045-1053, 1995.

23. Lee NO, Park JW, Lee JA, Shim JH, Kong SY, Kim KT and Lee YS: Dual action of a selective cyclooxygenase-2 inhibitor on vascular endothelial growth factor expression in human hepatocellular carcinoma cells: novel involvement of discoidin domain receptor 2. J Cancer Res Clin Oncol 138: 73-84, 2012.

24. Eisermann K, Broderick CJ, Bazarov A, Moazam MM and Fraizer GC: Androgen up-regulates vascular endothelial growth factor expression in prostate cancer cells via an Sp1 binding site. Mol Cancer 12: 7, 2013.

25. Lee KY, Lee JW, Nam HJ, Shim JH, Song Y and Kang KW: PI3-kinase/p38 kinase-dependent E2F1 activation is critical for Pin1 induction in tamoxifen-resistant breast cancer cells. Mol Cells 32: 107-111, 2011.

26. Cao X, Geradts J, Dewhirst MW and Lo HWU: pregulation of VEGF-A and CD24 gene expression by the tGLI1 transcription factor contributes to the aggressive behavior of breast cancer cells. Oncogene 31: 104-115, 2012.

27. Takayama K, Reynolds PN, Adachi Y, Kaliberova L, Uchino J, Nakanishi Y and Curiel DT: Vascular endothelial growth factor promoter-based conditionally replicative adenoviruses for pan-carcinoma application. Cancer Gene Ther 14: 105-116, 2007.

28. Koshikawa N, Takenaga K, Tagawa M and Sakiyama S: Therapeutic efficacy of the suicide gene driven by the promoter of vascular endothelial growth factor gene against hypoxic tumor cells. Cancer Res 11: 2936-2941, 2000.

29. Kong H, Huang ZH, Li Z, Yu JL, Chen HJ and Han XJ: Preliminary effect of VEGF promoter-driven recombinant adenovirus containing double suicide genes on apoptosis of human gastric carcinoma cells. Nan Fang Yi Ke Da Xue Xue Bao 27: 1152-1155, 2007 (In Chinese).

30. Li XH, Zhou P, Wang LH, Tian SM, Qian Y, Chen LR and Zhang P: The targeted gene (KDRP-CD/TK) therapy of breast cancer mediated by SonoVue and ultrasound irradiation in vitro. Ultrasonics 52: 186-191, 2012.

31. Su GQ, Su G and Huang ZH: Adenovirus-mediated tissue-targeted expression of the CDglyTk gene for the treatment of breast cancer. Mol Med Rep 6: 321-329, 2012.

32. Kang NH, Hwang KA, Yi BR, Lee HJ, Jeung EB, Kim SU and Choi KC: Human amniotic fluid-derived stem cells expressing cytosine deaminase and thymidine kinase inhibits the growth of breast cancer cells in cellular and xenograft mouse models. Cancer Gene Ther 19: 412-419, 2012. 